\title{
The role of mitochondria in physical activity and its adaptation on aging
}

\author{
FERRO, M. S. *, RODRIGUES, G. M. and DE SOUZA, R. R. \\ Post Graduation Course Aging Sciences, Universidade São Judas Tadeu - USJT, \\ Rua Taquari, 546, Mooca, CEP 03166-000, São Paulo, SP, Brazil \\ *E-mail: marceloferro26@gmail.com
}

\begin{abstract}
Introduction: The mitochondria are essential in numerous physiological processes, including energy production, redox potential, modulation of calcium and several metabolic pathways. When the number or mitochondrial activity is insufficient, the human body quickly goes into fatigue due to ATP deficiency. Methods: The principal data base were used: PubMed, Medline, Scielo and Lilacs. Keywords used were: mitochondrial biogenesis, aging, organic acids, enzyme changes and respiratory chain. Groups considered: young and aged. Types of training: aerobic and anaerobic. Papers dealing with pathogies were not considered. The oxidative capacity of muscle tissue and the preservation of mitochondria depends on the mitochondrial biogenesis that occurs through the transcription factor proliferator-activator receptor- $\gamma$ coactivator $1 \alpha$ (PGC- $1 \alpha$ ). The oxidative process and the progressive change in the biogenesis of mitochondria have direct influence on the aging of muscle tissue. The regulation of the biogenesis occurs through the PGC- $1 \alpha$ combined with nuclear respiratory factor 1 (NRF1). Abnormalities in mitochondria and mutagenesis in mitochondrial DNA (mtDNA) are tied to multi-system degeneration, as well as intolerance to stress, and decreased energy in aging in humans, rats and monkeys. The mitochondrial functions are dramatically altered in heart disease, demonstrating a decrease in expression of PGC-1 $\alpha$, which plays a key role in the coordination of energy metabolism. This process can be reversed by the PGC- $1 \alpha$ itself. The identification of compounds capable of activating the transcription of PGC-l $\alpha$ could be part of future therapies to reverse pathologies associated with the decline of this organelle. Morpho-physiological and biochemical changes of these organelles directly reflect the physiological performance of all body tissues. Conclusion: evidence demonstrated that physical activity, both in young and aged is a major ally in mitochondrial biogenesis by activating the transcription of PGC - $1 \alpha$ and that future nutritional interventions may be of great aid in the health and performance of mitochondria. However, further studies are needed in order to understand and clarify this operation, since currently these mechanisms are only partially known.
\end{abstract}

Keywords: mitochondrial biogenesis, aging, organic acids, enzyme changes, respiratory chain.

\section{Introduction}

The mitochondrion is a type of organelle that contains different characteristics, compared to other organelles. It is the only one that has a double membrane, an internal and another external, and carries its own genome. It uses oxygen and other substrates for most of the production of adenosine triphosphate (ATP) in the cells, producing reactive oxygen species (ROS) in this process (PETERSON, JOHANNSEN and RAVUSSIN, 2012). The mitochondria are essential in numerous physiological processes, including production of energy, redox potential, modulation of calcium and several metabolic pathways (CALI, OTTOLINI and BRINI, 2012). Several studies in individuals with insulin resistance have addressed the morphological changes that occur in the mitochondria, among which the reduction of its mass and volume, decrease in oxidative capacity and alterations in gene expression of the peroxisome proliferator-activator receptor- $\gamma$ coactivatorl $\alpha$ (PGC-l $\alpha$ ) in the skeletal muscle tissue (LI, FAN, XU et al., 2011). These organelles also participate in other cellular processes, including signal transduction, cell cycle regulation, oxidative stress, apoptosis and thermogenesis (PETERSON, JOHANNSEN and RAVUSSIN, 2012).
When the number or activity of mitochondria is insufficient, the human body quickly goes into fatigue by ATP deficiency. Therefore, controlling the amount and function of mitochondria is extremely important in the pursuit of optimization of the energy balance of tissues (JEONG, CHO, KIM et al., 2012). According to Cali, Ottolini and Brini (2012), the number, size, shape and distribution of mitochondria within the cells is well controlled. The same authors also reported evidence that mitochondrial abnormalities and oxidative damage are key points to trigger neurodegenerative diseases.

Mitochondria are responsible for $95 \%$ of ATP production in the cells, and are very numerous in tissues that require large amounts of energy such as the heart, skeletal muscle and neurons (VADVALKAR, BAILY, MATSUZAKI et al., 2013). Only mitochondria of the cardiac muscle are responsible for producing approximately six kilos of ATP/day (DORN, 2013). Substrates such as glucose, fatty acids and amino acids are converted into energy within the mitochondria in the cycle of tricarboxylic acid (TCA) by the electron transport system (ETS) for the production of ATP. This process is called oxidative phosphorylation (OXPHOS), and plays a fundamental role in many physiological cellular mechanisms 
(PETERSON, JOHANNSEN and RAVUSSIN, 2012). The same authors reported that there is a decline in the biochemical and bioenergetic functions of mitochondria with aging, showing decrease of energy in the process. The aging of mitochondria is linked to mutations in the mitochondrial DNA ( $\mathrm{mtDNA}$ ) resulting in possible decline of functions in the tissues (SAFDAR, BOURGEOIS, OGBORN et al., 2011).

The human search for improved performance - be it in sports, or even in everyday life - has always been one of the most complex and difficult tasks for professionals in the health area. Therefore, the aim of this paper is to describe the mechanisms and possible alterations in mitochondria, its reflection in the energy production of the tissues, physical activity and aging. The specific objective is to present new data of the biochemical and bioenergetic functions of mitochondria and verify its influence on physical performance and aging.

\subsection{Mitochondrial biogenesis}

Mitochondrial biogenesis is a complex process that requires the coordinated expression of approximately 1,500 proteins encoded between the nuclear and mitochondrial genomes (SAFDAR, BOURGEOIS, OGBORN et al., 2011). In tissues that require high oxidative process because of high energy demands, such as skeletal muscle and cardiac muscle, mitochondria are essential for energy production for its perfect functioning.

The oxidative capacity of muscle tissue and the preservation of mitochondria depends on the mitochondrial biogenesis that occurs through the PGC- $1 \alpha$, considered a master regulator of the energy metabolism (RUIZ, COURILLEAU, JULLIAN et al., 2012). Physical activity has been a crucial factor in the induction and increase of mitochondria in muscle tissue due to the stimulation that the muscle is subjected to in endurance training (STEINER, MURPHY, MCCLELLAN et al., 2011; WANG, MASCHER, PSILANDER et al., 2011). Endurance exercises are the most potent physiological inducers in mitochondrial biogenesis in the muscle tissue, but also in many other tissues, including the brain, heart, adipose tissue and liver (SAFDAR, BOURGEOIS, OGBORN et al., 2011). The oxidative process and the progressive change in the biogenesis of mitochondria have direct influence on the heart muscle aging (QI, HE, SU et al., 2011).

Authors such as Li, Fan, Xu et al. (2011), in a study with animals, showed an increase in the activity of the citrate synthase enzyme in rats subjected to unremitting exercise for three months, stating that there was an increase in the density of mitochondria in muscle tissue. Interestingly, Wang, Mascher, Psilander et al. (2011) demonstrated in their study that exercises of endurance and strength combined, resulted in greater adaptive signaling in mitochondrial biogenesis compared to endurance exercise only. Mitochondrial biogenesis induced by physical activity of high-performance proved to be a regulator of genes in transcription from the nucleus to mitochondria by the PGC- $1 \alpha$ itself (SAFDAR, BOURGEOIS, OGBORN et al., 2011). This regulation occurs through the PGC- $1 \alpha$ in combination with the nuclear respiratory factor 1 (NRFl). The NRFl starts the transcription responsible for mitochondrial biogenesis, whereas the PGC- $1 \alpha$ stabilizes the gene regulation network (JEONG, CHO, KIM et al., 2012). The same authors also reported that mitochondrial biogenesis is a complex process involving several proteins and nuclear genes, suggesting the need for further studies to better elucidate this process.

\subsection{Mitochondrial RNA and the coding of respiratory chain}

The transfer RNA (tRNA) are essential adapters in the decoding of messenger RNA (mRNA) by the ribosome. Thus, their biogenesis is crucial for cell survival, demonstrating that changes in the mitochondrial tRNA (mt tRNA), although in small numbers, seem to be crucial to achieve the proper formation of proteins of this organelle (VILARDO, NACHBAGAUER, BUZET et al., 2012).

The regulation of expression of mtDNA is the most important key in OXPHOS, because it encodes 13 subunits of the respiratory chain and ATP synthase (SPAHR, HABERMANN, GUSTAFSSON et al., 2012). The authors also stated that despite its importance, the regulation of the mtDNA gene expression in response to cellular and metabolic demands is only partially understood. According to Duarte and Videira (2012), in mammals, 22 tRNA and 2 rRNA of mitochondrial origin, together with over a hundred proteins of nuclear origin, permit the synthesis of the OXPHOS 13 polypeptides encoded by the mtDNA. The cytochrome $\mathrm{c}$ oxidase (COX, complex IV), is part of the mitochondrial biogenesis linked to the 13 subunits mentioned above, which are complementary with the other COX of the complex I-III, and are encoded and activated by the transcription level of the mitochondrial transcription factor (TFAM) and mitochondrial transcription factor $\mathrm{B} 2\left(\mathrm{TFB}_{2} \mathrm{M}\right)$ (QI, HE, SU et al., 2011). In complex I, the NADH: ubiquinone, in humans, consists of 44 different subunits; seven encoded by mtDNA and the rest by nDNA. However, the process of how this complicated enzyme system is maintained, is only beginning to be understood (DIETEREN, KOOPMAN, SWARTS et al., 2012).

Mitochondrial biogenesis can also be promoted via sirtuin 1 or silent regulator information T1 (SIRT1), a protein deacetylase that acts as a silent information regulator (STEINER, MURPHY, MCCLELLAN et al., 2011). According to the authors, this protein interacts with deacetylation and activates the PGC-l $\alpha$, and together with NRF-1, promotes the mitochondrial biogenesis (Figure 1).

\section{Electron Transport and Energy Production}

The electron transport chain connects the center of energy production in carbohydrate metabolism with ATP synthesis (SELIVANOV, CASCANTE, FRIEDMAN et al., 2012). First, the glucose is oxidized to pyruvate through glycolysis in the cytosol. Pyruvate is transported into the mitochondrial matrix by the pyruvate dehydrogenase forming acetyl coenzyme A (Acetyl-CoA). The acetyl-CoA initiates the turn of the citric acid cycle, where the NAD is reduced to NADH and the FAD is reduced to $\mathrm{FADH}_{2}$, both serving as substrates for the OXPHOS (RAMSDEN, HO, HO et al., 2012). This chain transforms the free energy released by the oxidation of NADH and succinate in a form of transmembrane electrochemical potential, which is used for ATP synthesis (SELIVANOV, CASCANTE, FRIEDMAN et al., 2012). The oxidation-reduction process, NADH: ubiquinone, begins through the complex I of the respiratory chain, catalyzing the oxidation of $\mathrm{NADH}$, reducing ubiquinone and using the energy generated by this process to transfer protons across the inner mitochondrial membrane (DIETEREN, KOOPMAN, SWARTS et al., 2012). All five oxidative phosphorylation complexes (complex 


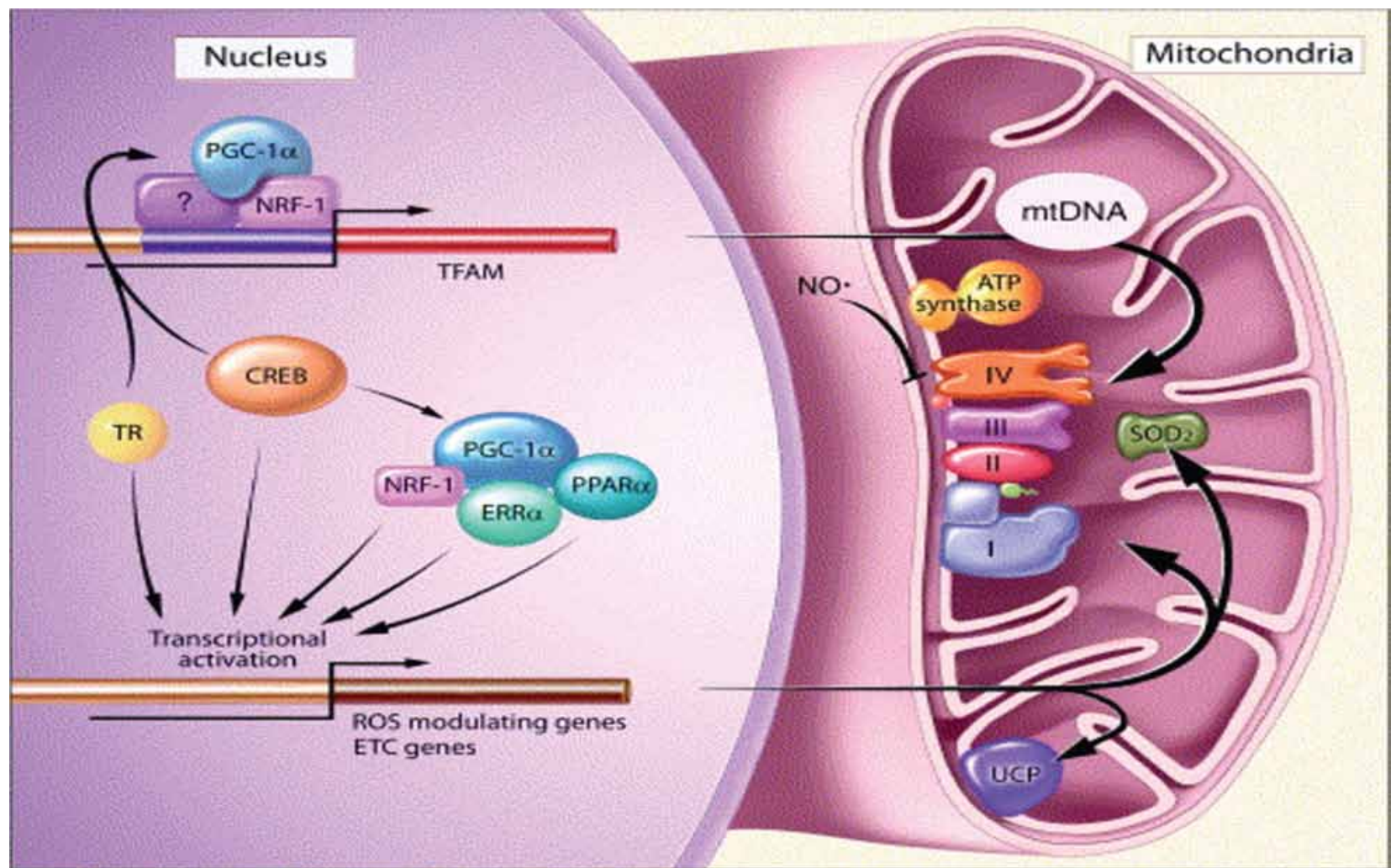

Figure 1. Mitochondrial biogenesis through the transcription factors peroxisome proliferator-activator receptor- $\gamma \operatorname{coactivator} \mathbf{l} \alpha(\mathbf{P G C}-\mathbf{1} \alpha)$, nuclear respiratory factor 1 (NRF1) and mitochondrial transcription factor (TFAM). Source: McLeod, Pagel and Sack (2005).

$\mathrm{I}-\mathrm{V})$ participate in a concerted system of electron transport across the inner membrane (Figure 2). The cellular energy production via electron transport for the transfer of protons through the intermembrane space (complex I-IV), combined with the transfer of energy released in this system, converts the result of the proton gradient for ATP production in complexV (CANNINO, EL-KHOURY, PIRINEN et al., 2012).

Not all electrons can pass through the electron transport chain until the complex IV. Some electrons escape through the complex I and III giving rise to the harmful formation of reactive oxygen species (ROS) (RAMSDEN, HO, HO et al., 2012). The same authors reported that the ROS production process is particularly intense when complex I is inhibited. Although the cells have developed ways to handle ROS, once formed, a means of preventing or minimizing the formation of ROS is energetically advantageous. Thus, a leakage of protons back into the matrix, avoiding the complex $\mathrm{V}$, results in a significant reduction in ROS formation, while having little effect on the synthesis of ATP. According to the authors, the slight decrease of the potential difference across the inner mitochondrial membrane has shown to inhibit the formation of $\mathrm{H}_{2} \mathrm{O}_{2}$ in around $70 \%$.

\subsection{Possible enzymatic changes in energy metabolism}

One of the most important enzyme complexes of the energy metabolism is the pyruvate dehydrogenase complex (PDC) (JEONG, CHO, KIM et al., 2012). This complex consists of three specific enzymes, the pyruvate dehydrogenase (El), dihydrolipoamide transacetylase (E2) and dihydrolipoamide dehydrogenase (E3) (BOWKER-KINLEY, DAVIS, WU et al., 1998). The PDC is regulated by the inhibition feedback of the acetyl-CoA and NADH, both final products of the oxidative decarboxylation of pyruvate and beta-oxidation of free fatty acids (JEONG, CHO, KIM et al., 2012). El catalyzes the oxidative decarboxylation of pyruvate using thiamine pyrophosphate as a cofactor, followed by the reduced acetylation of the lipoil portion covalently bound to E2, which transfers the CoASH group releasing acetyl-CoA as a product. E3 contains FAD as a cofactor, and completes the cycle reaction by reoxidation of the lipoil groups of E2, using NAD as electron receptor (AHSAN, SWATEK, ZHANG et al., 2012).

The same way that the pyruvate dehydrogenase (PDH), the alpha-ketoglutarate dehydrogenase (alpha-KGDH) and branched-chain amino acid dehydrogenase $(\mathrm{BCKDH})$ are of vital importance not only in energy metabolism, but also in the metabolism of amino acids. These three sets are called alpha-ketoacid dehydrogenase complex (KGDC) (STORM and MULLER, 2012). The pyruvate dehydrogenase kinase (PDK) and pyruvate dehydrogenase phosphatase (PDP) are key regulators of $\mathrm{PD}$ with opposite mechanisms in regulatory activity (JEONG, CHO, KIM et al., 2012). The authors demonstrated that levels of acetyl-CoA, NADH and ATP increased the activity of PDK, while levels of pyruvate, CoASH, ADP and $\mathrm{NAD}+$ inhibited its activity (Figure 3 ). The genetic defect in the PD complex can lead to neurological and neuromuscular degeneration, and during childhood, usually to death (PATEL, O'BRIEN, SUBRAMONY et al., 2012). 
The biochemical consequences of PDC deficiency occurring at the cellular level remain poorly understood. Studies using spectroscopy to examine the fate of $\mathrm{U}-13 \mathrm{C}$-glucose in primary cultures of skin fibroblasts from patients with PDC deficiency suggest that, regardless of the underlying mutation, glycolysis and lactate production are increased, and carbon glucose is diverted from the PD to the pyruvate carboxylase (PC), and the flow through the tricarboxylic acid cycle (TCA) is reduced (GLUSHAKOVA, JUDGE, CRUZ et al., 2011).

\subsection{Decline in energy production and effects on the performance}

Abnormalities in mitochondria and mtDNA mutagenesis are linked to the multi-system degeneration, intolerance to stress and decreased energy in aging in humans, rats and monkeys (SAFDAR, BOURGEOIS, OGBORN et al., 2011). In another study, the same authors, reported that physical inactivity (sedentary lifestyle) is a major threat to global public health. It is a risk factor for inducing primary sarcopenia, cardiovascular

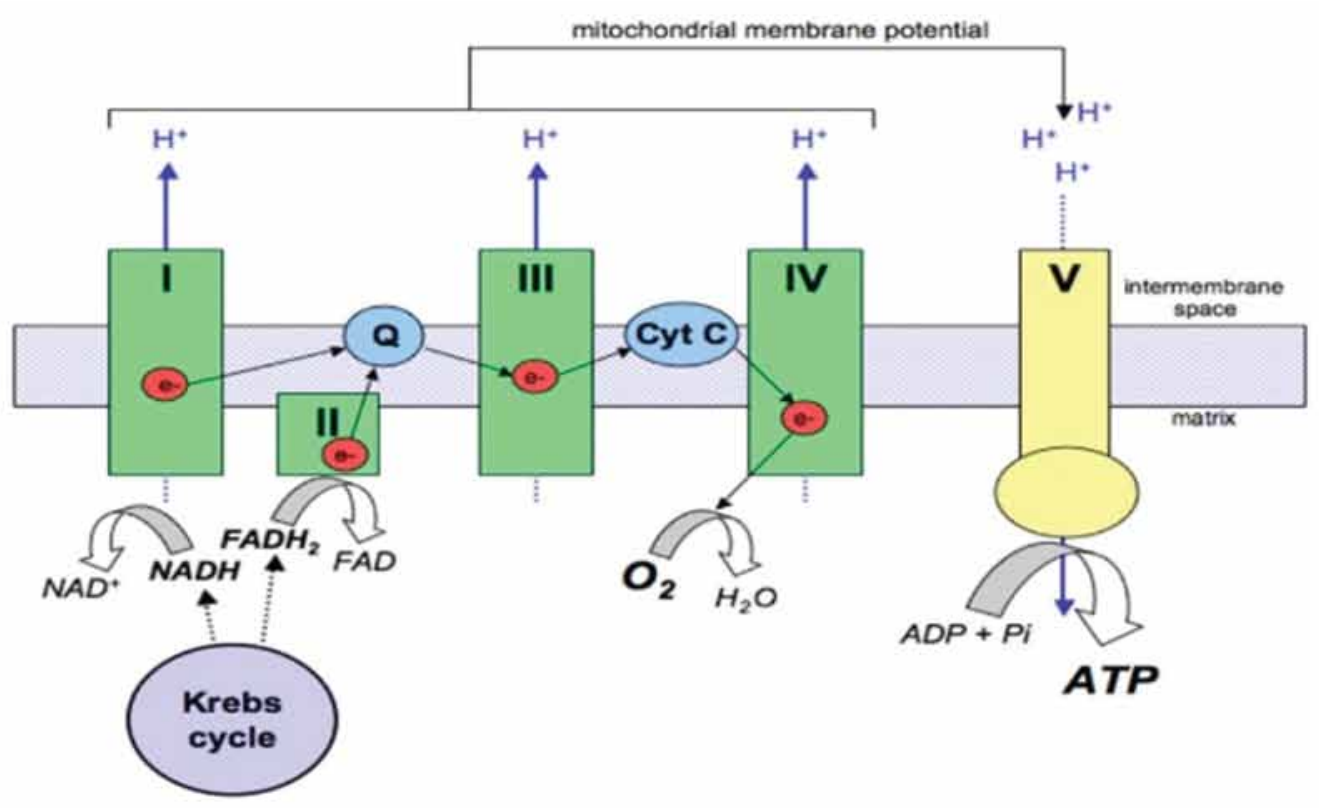

Figure 2. The five complexes of oxidative phosphorylation (OXPHOS) (complex I-V) in the electron transport across the inner membrane and the proton-motive force in ATP synthesis dependent of NADH, FADH, coenzyme Q and cytochrome C. Source: Protti and Singer $(2006,10: 228)$.

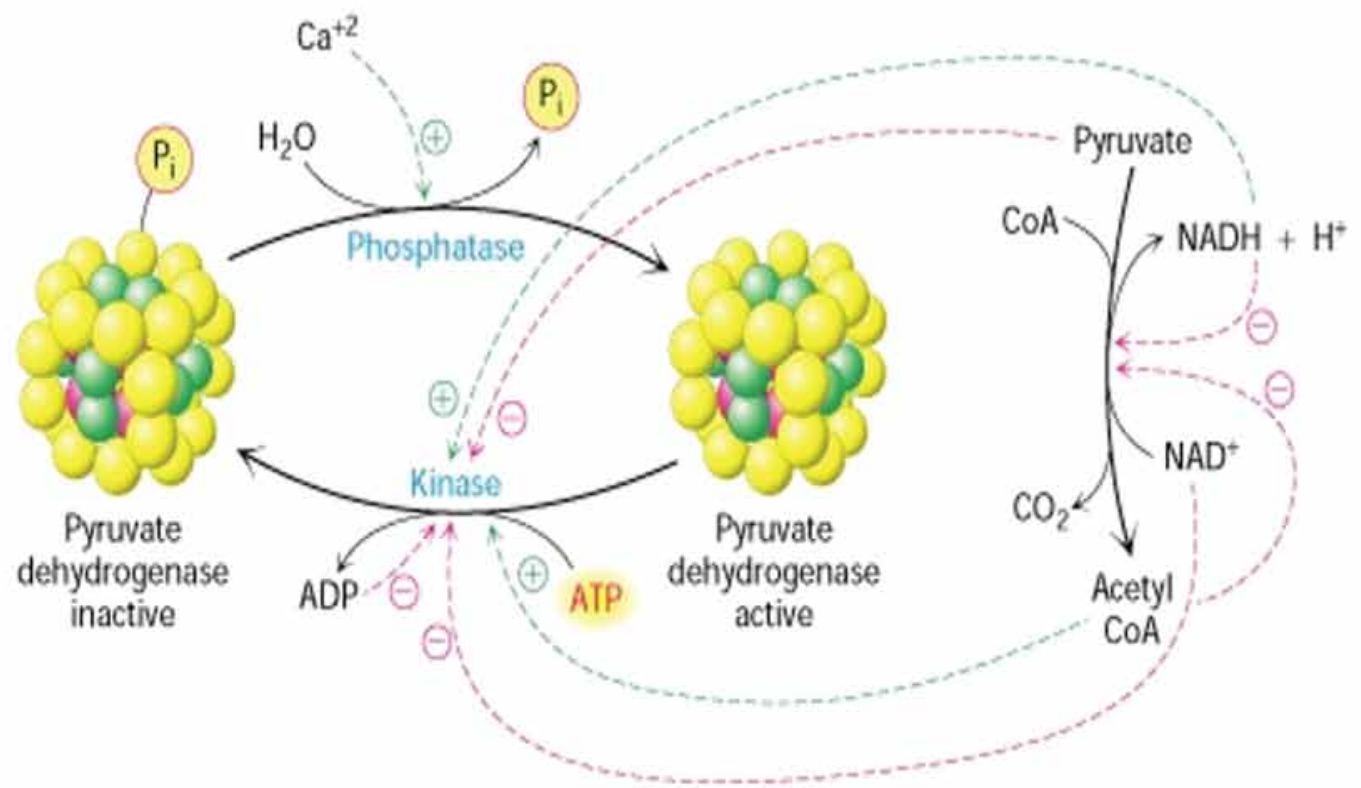

Figure 3. Metabolism of pyruvate dehydrogenase, inactivated by the pyruvate dehydrogenase kinase and activated by pyruvate dehydrogenase phosphatase. Source: Mundo da Bioquímica (2012). 
diseases, diabetes, obesity, stroke, hypertension and other chronic diseases, including colon cancer and breast cancer, kidney disease, osteoporosis, osteoarthritis and neuromuscular and neurometabolic diseases.

Recently, was identified a metabolic regulation mechanism of mitochondrial protein, the deacetylase Sirt3, which is linked to deacetylation of complex I, conducting its activation (CANNINO, EL-KHOURY, PIRINEN et al., 2012). In a paper on propionic aciduria (PA), Schwab, Sauer, Okun et al. (2006) demonstrated that patients with PA had, not only a severe disturbance in mitochondrial energy metabolism in vivo muscular tissue, but also the propionyl CoA, when placed in vitro, demonstrated to induce mitochondrial dysfunction. Dysfunctional mitochondria play a key role in reducing muscle function, providing evidence that biochemical and bioenergetic changes in mitochondria not only reflect the loss of the function of muscle tissue, but are also associated with certain pathologies such as insulin resistance, systemic inflammation and infiltration of fat in the muscle (PETERSON, JOHANNSEN and RAVUSSIN, 2012). Oral administration of propionylL-carnitine (PLC) improved the state of insulin resistance developed by obese animals and decreased the cardiovascular risk associated with this metabolic alteration, probably through correction of mitochondrial function (MINGORANCE, DULUC, CHALOPIN et al., 2012) (Figure 4).

Recent studies have reported the action of an enzyme called $\mathrm{NAD}(\mathrm{P}) \mathrm{H}$ : quinone oxidoreductase $\left(\mathrm{NQO}_{1}\right)$, which is directly involved in the cellular aging process. According to the authors, this enzyme modulates the NAD + / NADH relation, one of the known causes of cellular aging and aging-related diseases, which would be directly linked mitochondria and energy production. The function of this enzyme is decreased in aged tissues, and can be minimized with the induction of caloric restriction in diet. In addition to the mechanism of regulation of PDC, other determinant factors on the energy metabolism are the conversion of cholesterol to pregnenolone within the mitochondria for the synthesis of steroid hormones, particularly testosterone (DUARTE, PODEROSO, COOKE et al., 2012), the action of magnesium in the hydrolysis of ATP (AGARWAL, IEZHITSA and AGARWAL, 2014), the five complexes of the OXPHOS system and ATP synthase (CANNINO, EL-KHOURY, PIRINEN et al., 2012; DIETEREN, KOOPMAN, SWARTS et al., 2012) and the preservation of mitochondrial biogenesis (RUIZ, COURILLEAU, JULLIAN et al., 2012).

\section{Discussion}

The morpho-physiological and biochemical changes of mitochondria proved to be key factors for cellular homeostasis, both in youth and aged. When Safdar, Bourgeois, Ogborn et al. (2011) reported abnormalities in mitochondria and mutagenesis in mtDNA related to the multi-system degeneration in mammals, we are in face of various processes of cellular energy imbalance. In order that a cell of the pancreas, for example, releases insulin into the bloodstream, it requires that the calcium channels $(\mathrm{Ca}+)$ are open to the pancreatic vesicles in the presence of the own $\mathrm{Ca}+$, and release the hormone stored therein. This process is possible only through the synthesis of ATP produced in the mitochondria of islets of Langerhans. Without ATP, the potassium channels remain open, which hinders the opening of calcium channels by inhibiting its entry (TAKEI, DEZAKI, ISHII et al., 2013).
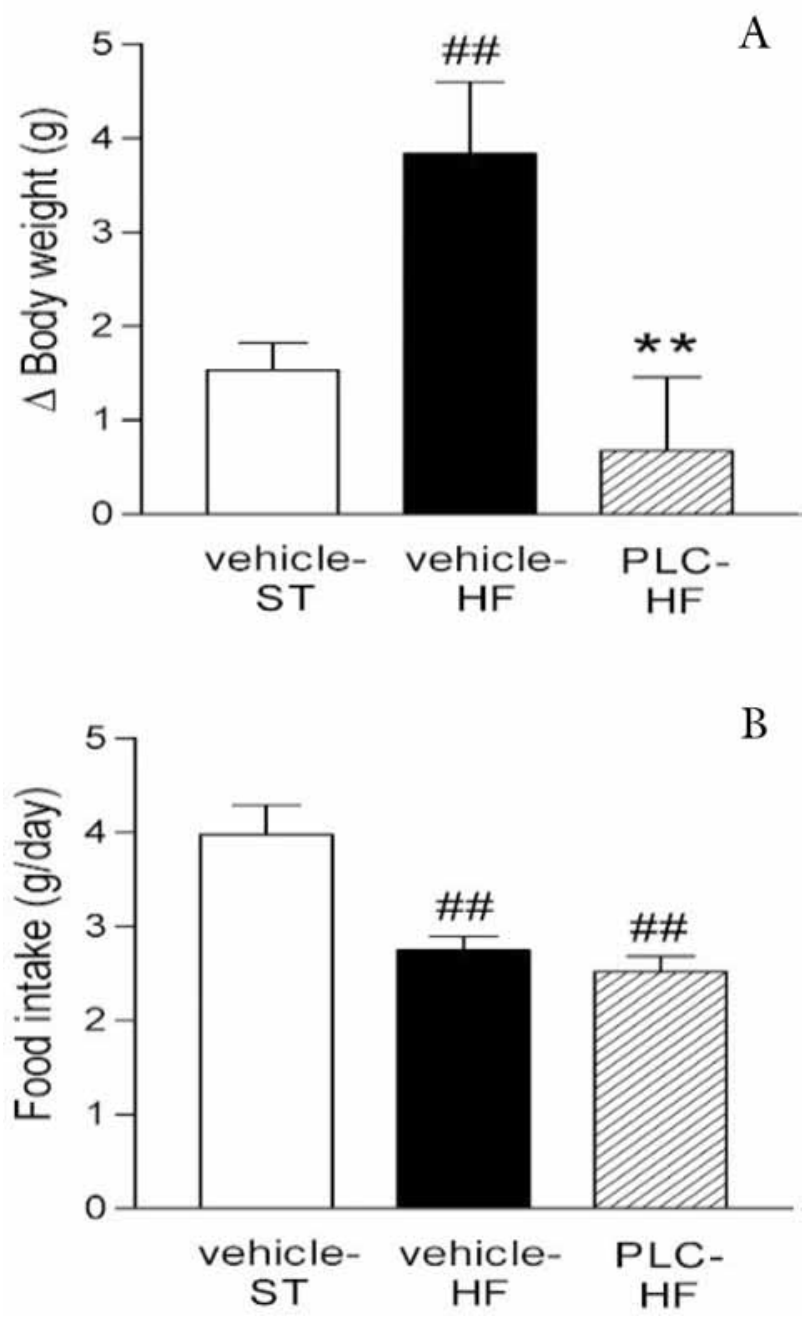

Figure 4. A - Standard diet (ST), high fat diet (HF) and high fat diet with propionyl-L-carnitine (PLC-HF). B - Food intake in standard diet (ST), high fat diet (HF) and high fat diet with propionyl-L-carnitine (PLC-HF). Source: Mingorance, Duluc, Chalopin et al. (2012).

According to Djafarzadeh, Vuda, Takala et al. (2012), the pathogens associated with mitochondrial dysfunction are multifactorial, but the formation of nitric oxide (NO), the overproduction of ROS, the antioxidant deficiency and the increased permeability of the mitochondrial inner membrane, are the most likely contributions for these activities. Safdar, Bourgeois, Ogborn et al. (2011) makes an analogy between the reduction of quality of mitochondria, aging and related diseases such as cancer, diabetes, obesity, dementia, osteoporosis and even neurometabolic syndromes. The same authors believe that one possible approach to mitigate these primary deficiencies would be to increase the residual oxidative capacity of mitochondria by increasing mitochondrial functional mass of the affected tissues through physical activity.

Ruiz, Courilleau, Jullian et al. (2012) showed that mitochondrial functions are dramatically altered in heart disease, demonstrating a decrease in expression of PGC- $1 \alpha$, which plays a key role in coordinating energy metabolism. According to both authors, this process can be reversed through the PGC-l $\alpha$ itself. The identification of compounds 
capable of activating transcription of PGC- $1 \alpha$ could be part of future therapies to reverse pathologies associated with the decline of this organelle, reported the authors. Both Li, Fan, Xu et al. (2011) as Peterson, Johannsen and Ravussin (2012) also reported the benefits of induced physical activity in the increase of mitochondrial biogenesis in rats, by associating with increased expression of mRNA transcription in response to a higher demand for energy related to physical exercise. However, when analyzing all the evidence on the biochemical and morphological changes of mitochondria, there is still little evidence of why these organelles are altered with aging.

So far, it is known that caloric restriction and physical activity are some of the physiological processes that can biologically change the mitochondrial biogenesis. Some substances such as resveratrol and quercetin, the combination of substances such as alpha lipoic acid, nicotinamide and L-acetyl carnitine, as well as the pyrroloquinoline quinone demonstrated positive effects in both the mitochondrial biogenesis, as in increase of physiological functions of these organelles when it presented abnormalities (BAUERLY, HARRIS, CHOWANADISAI et al., 2011). The same authors also reported positive effects in the PGC- $1 \alpha$, in carnitine palmitoyltransferase and activation of complex I and II of the respiratory chain by influencing the increase in mRNA levels in the administration of these supplements. However, these studies still need more details about its mechanisms, state the authors.

\section{Conclusion}

The morpho-physiological and biochemical changes of these organelles directly reflect the physiological performance of all tissues, principally during the aging process. Evidence showed that physical activity is a major ally in mitochondrial biogenesis by activating the transcription of PGC- $1 \alpha$, and that future nutritional intervention may be of great aid in the health and performance of mitochondria. It seems clear that the secret of the cell performance is the maintenance of mitochondrial biogenesis. However, as mentioned by several authors in the present study, further studies are needed in order to understand and clarify this operation, since currently these mechanisms are only partially known.

\section{References}

AGARWAL, R., IEZHITSA, L. and AGARWAL, P. Pathogenetic role of magnesium deficiency in ophthalmic diseases. Biometals, 2014, vol. 27, n. 1, p. 5-18. PMid:24233809.

AHSAN, N., SWATEK, K.N., ZHANG, J., MIERNYK, J.A., XU, D. and THELEN, JJ. "Scanning mutagenesis" of the amino acid sequences flanking phosphorylation site 1 of the mitochondrial pyruvate dehydrogenase complex. Frontiers in Plant Science, 2012, vol. 3, p. 1-10. http://dx.doi.org/10.3389/fpls.2012.00153. PMid:22811682.

BAUERLY, K., HARRIS, C., CHOWANADISAI, W., GRAHAM, J., HAVEL, P.J., TCHAPARIAN, E., SATRE, M., KARLINER, J.S. and RUCKER, RB. Altering pyrroloquinoline quinone nutritional status modulates mitochondrial, lipid, and energy metabolism in rats. PLoS One, 2011, vol. 6, n. 7, p. e21779. http://dx.doi.org/10.1371/ journal.pone.0021779. PMid:21814553.

BOWKER-KINLEY, M.M., DAVIS, W.I., WU, P., HARRIS, R.A. and POPOV, KM. Evidence for existence of tissue-specific regulation of the mammalian pyruvate dehydrogenase complex. The Biochemical Journal, 1998, vol. 329, n. 1, p. 191-196. http://dx.doi.org/10.1042/ bj3290191. PMid:9405293.
CALİ, T., OTTOLINI, D. and BRINI, M. Mitochondrial Ca(2+) and neurodegeneration. Cell Calcium, 2012, vol. 52, n. 1, p. 73-85. http://dx.doi.org/10.1016/j.ceca.2012.04.015. PMid:22608276.

CANNINO, G., EL-KHOURY, R., PIRINEN, M., HUTZ, B., RUSTIN, P., JACOBS, H.T. and DUFOUR, E. Glucose modulates respiratory complex I activity in response to acute mitochondrial dysfunction. The Journal of Biological Chemistry, 2012, vol. 287, n. 46, p. 38729-38740. http://dx.doi.org/10.1074/jbc.M112.386060. PMid:23007390.

DIETEREN, C.E., KOOPMAN, W.J., SWARTS, H.G., PETERS, J.G., MACZUGA, P., VAN GEMST, J.J., MASEREEUW, R., SMEITINK, J.A., NIJTMANS, L.G. and WILLEMS, PH. Subunitspecific incorporation efficiency and kinetics in mitochondrial complex I homeostasis. The Journal of Biological Chemistry, 2012, vol. 287, n. 50, p. 41851-41860. http://dx.doi.org/10.1074/jbc.M112.391151. PMid:23038253.

DJAFARZADEH, S., VUDA, M., TAKALA, J. and JAKOB, SM. Effect of remifentanil on mitochondrial oxygen consumption of cultured human hepatocytes. PLoS One, 2012, vol. 7, n. 9, p. e45195. http://dx.doi.org/10.1371/journal.pone.0045195. PMid:23028840.

DORN, GW 2nd. Mitochondrial dynamism and cardiac fate: a personal perspective. Circulation Journal, 2013, vol. 77, n. 6, p. 1370-1379. http://dx.doi.org/10.1253/circj.CJ-13-0453. PMid:23615052.

DUARTE, A., PODEROSO, C., COOKE, M., SORIA, G., CORNEJO MACIEL, F., GOTTIFREDI, V. and PODESTÁ, EJ. Mitochondrial fusion is essential for steroid biosynthesis. PLoS One, 2012, vol. 7, n. 9, p. e45829. http://dx.doi.org/10.1371/journal.pone.0045829. PMid:23029265.

DUARTE, M. and VIDEIRA, A. Defective valyl-tRNA synthetase hampers the mitochondrial respiratory chain in Neurospora crassa. The Biochemical Journal, 2012, vol. 448, n. 3, p. 297-306. http:// dx.doi.org/10.1042/BJ20120963. PMid:22957697.

GLUSHAKOVA, L.G., JUDGE, S., CRUZ, A., POURANG, D., MATHEWS, C.E. and STACPOOLE, PW. Increased superoxide accumulation in pyruvate dehydrogenase complex deficient fibroblasts. Molecular Genetics and Metabolism, 2011, vol. 104, n. 3, p. 255-260. http://dx.doi.org/10.1016/j.ymgme.2011.07.023. PMid:21846590.

JEONG, H.W., CHO, S.Y., KIM, S., SHIN, E.S., KIM, J.M., SONG, M.J., PARK, P.J., SOHN, J.H., PARK, H., SEO, D.B., KIM, W.G. and LEE, SJ. Chitooligosaccharide induces mitochondrial biogenesis and increases exercise endurance through the activation of Sirtl and AMPK in rats. PLoS One, 2012, vol. 7, n. 7, p. e40073. http://dx.doi. org/10.1371/journal.pone.0040073. PMid:22808092.

LI, P., FAN, W., XU, J., LU, M., YAMAMOTO, H., AUWERX, J., SEARS, D.D., TALUKDAR, S., OH, D., CHEN, A., BANDYOPADHYAY, G., SCADENG, M., OFRECIO, J.M., NALBANDIAN, S. and OLEFSKY, JM. Adipocyte NCoR knockout decreases PPAR $\gamma$ phosphorylation and enhances PPAR $\gamma$ activity and insulin sensitivity. Cell, 2011, vol. 147, n. 4, p. 815-826. http://dx.doi.org/10.1016/j.cell.2011.09.050. PMid:22078880.

MCLEOD, CJ., PAGEL, I. and SACK, MN. The mitochondrial biogenesis regulatory program in cardiac adaptarion to ischemia: a putative target for therapeutic intervetion. Trends in Cardiovascular Medicine, 2005, vol. 15, n. 3, p. 118-23.

Mingorance, C., DUlUC, L., CHALOPIN, M., SIMARD, G., DUCLUZEAU, P.H., HERRERA, M.D., ALVAREZ DE SOTOMAYOR, M. and ANDRIANTSITOHAINA, R. Propionyl$\mathrm{L}$-carnitine corrects metabolic and cardiovascular alterations in dietinduced obese mice and improves liver respiratory chain activity. PLoS One, 2012, vol. 7, n. 3, p. e34268. http://dx.doi.org/10.1371/ journal.pone.0034268. PMid:22457831.

MUNDO DA BIOQUÍMICA. Mundo da Bioquímica (blog sobre bioquimica). 2012. Available from: <www.mundodabioquimica. blogspot.com.br>. Access in: 5 Aug. 2014. 
PATEL, K.P., O'BRIEN, T.W., SUBRAMONY, S.H., SHUSTER, J. and STACPOOLE, PW. The spectrum of pyruvate dehydrogenase complex deficiency: clinical, biochemical and genetic features in 371 patients. Molecular Genetics and Metabolism, 2012, vol. 106, n. 3, p. 385-394. http://dx.doi.org/10.1016/j.ymgme.2012.03.017. PMid:22896851.

PETERSON C.M., JOHANNSEN D.L. and RAVUSSIN E. Skeletal muscle mitochondria and aging: a review. Journal of Aging Research, 2012, 2012, p. 194821.

PROTTI, A. and SINGER, M. Bench-to-bedside review: potential stretegies to protect or reverse mitochondrial dysfunction in sepsisinduced organ failure. Critical Care, 2006, vol. 10, n. 5, p. 228.

QI, Z., HE, J., SU, Y., HE, Q., LIU, J., YU, L., AL-ATTAS, O., HUSSAIN, T., DING, S., JI, L. and QIAN, M. Physical exercise regulates p53 activity targeting $\mathrm{SCO} 2$ and increases mitochondrial COX biogenesis in cardiac muscle with age. PLoS One, 2011, vol. 6, n. 7, p. e21140. http://dx.doi.org/10.1371/journal.pone.0021140. PMid:21750704.

RAMSDEN, D.B., HO, P.W., HO, J.W., LIU, H.F., SO, D.H., TSE, H.M., CHAN, K.H. and HO, SL. Human neuronal uncoupling proteins 4 and 5 (UCP4 and UCP5): structural properties, regulation, and physiological role in protection against oxidative stress and mitochondrial dysfunction. Brain and Behavior, 2012, vol. 2, n. 4 , p. 468-478. http://dx.doi.org/10.1002/brb3.55. PMid:22950050.

RUIZ, M., COURILlEAU, D., JULliAN, J.C., FORTIN, D., VENTURA-CLAPIER, R., BLONDEAU, J.P. and GARNIER, A. A cardiac-specific robotized cellular assay identified families of human ligands as inducers of PGC- $1 \alpha$ expression and mitochondrial biogenesis. PLoS One, 2012, vol. 7, n. 10, p. e46753. http://dx.doi. org/10.1371/journal.pone.0046753. PMid:23056435.

SAFDAR, A., BOURGEOIS, J.M., OGBORN, D.I., LITTLE, J.P., HETTINGA, B.P., AKHTAR, M., THOMPSON, J.E., MELOV, S., MOCEllin, N.J., KUJOTH, G.C., PROLlA, T.A. and TARNOPOLSKY, MA. Endurance exercise rescues progeroid aging and induces systemic mitochondrial rejuvenation in mtDNA mutator mice. Proceedings of the National Academy of Sciences of the United States of America, 2011, vol. 108, n. 10, p. 4135-4140. http://dx.doi. org/10.1073/pnas.1019581108. PMid:21368114.

SCHWAB, M.A., SAUER, S.W., OKUN, J.G., NIJTMANS, L.G., RODENBURG, R.J., VAN DEN HEUVEL, L.P., DRÖSE, S., BRANDT, U., HOFFMANN, G.F., TER LAAK, H., KÖLKER, S. and SMEITINK, JA. Secondary mitochondrial dysfunction in propionic aciduria: a pathogenic role for endogenous mitochondrial toxins. The Biochemical Journal, 2006, vol. 398, n. 1, p. 107-112. http:// dx.doi.org/10.1042/BJ20060221. PMid:16686602.
SELIVANOV, V.A., CASCANTE, M., FRIEDMAN, M., SCHUMAKER, M.F., TRUCCO, M. and VOTYAKOVA, TV. Multistationary and oscillatory modes of free radicals generation by the mitochondrial respiratory chain revealed by a bifurcation analysis. PLoS Computational Biology, 2012, vol. 8, n. 9, p. el002700. http://dx.doi.org/10.1371/ journal.pcbi.1002700. PMid:23028295.

SPÅHR, H., HABERMANN, B., GUSTAFSSON, C.M., LARSSON, N.G. and HALLBERG, BM. Structure of the human MTERF4-NSUN4 protein complex that regulates mitochondrial ribosome biogenesis. Proceedings of the National Academy of Sciences of the United States of America, 2012, vol. 109, n. 38, p. 15253-15258. http://dx.doi. org/10.1073/pnas.1210688109. PMid:22949673.

STEINER J.L., MURPHY E.A., MCCLELLAN J.L., CARMICHAEL M.D. and DAVIS J.M. Exercise training increases mitochondrial biogenesis in the brain. Journal of Applied Physiology, 2011, vol. 111, n. 4, p. 1066-1071.

STORM, J. and MÜLLER, S. Lipoic acid metabolism of Plasmodium: a suitable drug target. Current Pharmaceutical Design, 2012, vol. 18, n. 24, p. 3480-3489. PMid:22607141.

TAKEI, M., DEZAKI, K., ISHII, H., NISHIO, S., SATO, Y., SUZUKI, S., YADA, T. and KOMATSU, M. A new experimental model of ATPsensitive $\mathrm{K}^{+}$channel-independent insulinotropic action of glucose: a permissive role of cAMP for triggering of insulin release from rat pancreatic $\beta$-cells. Endocrine Journal, 2013, vol. 60, n. 5, p. 599-607. http://dx.doi.org/10.1507/endocrj.EJ12-0388. PMid:23327802.

VADVALKAR, S.S., BAILY, C.N., MATSUZAKI, S., WEST, M., TESIRAM, Y.A. and HUMPHRIES, KM. Metabolic inflexibility and protein lysine acetylation in heart mitochondria of a chronic model of type 1 diabetes. The Biochemical Journal, 2013, vol. 449, n. 1, p. 253-261. http://dx.doi.org/10.1042/BJ20121038. PMid:23030792.

VILARDO, E., NACHBAGAUER, C., BUZET, A., TASCHNER, A., HOLZMANN, J. and ROSSMANITH, W. A subcomplex of human mitochondrial RNase $\mathrm{P}$ is a bifunctional methyltransferase-extensive moonlighting in mitochondrial tRNA biogenesis. Nucleic Acids Research, 2012, vol. 40, n. 22, p. 11583-11593. http://dx.doi. org/10.1093/nar/gks910. PMid:23042678.

WANG L., MASCHER H., PSILANDER N., BLOMSTRAND E. and SAHLIN K. Resistance exercise enhances the molecular signaling of mitochondrial biogenesis induced by endurance exercise in human skeletal muscle. Journal of Applied Physiology, 2011, vol. 111, n. 5, p. 1335-1344. 